\title{
PRESEPSI MAHASISWA PRODI PENDIDIKAN TEKNIK ELEKTRO ANGKATAN 2018 TERHADAP PELAYANAN ADMINISTRASI JURUSAN TEKNIK ELEKTRO UNIVERSITAS NEGERI PADANG
}

\author{
Fikra Aulia Rizki \\ Program Studi Pendidikan Teknik Elektro \\ Email: fikraaulia2016@gmail.com
}

\begin{abstract}
Abstrak
Administrasi merupakan salah satu komponen untuk mengatur segala hal yang berkaitan dengan penyelenggaraan pendidikan pada perguruan tinggi. Pelayanan administrasi ini difokuskan pada pemberian bantuan kepada mahasiswa dalam hal registrasi, mendapatkan bahan ajar, transkrip, ijazan dan sistem informasi. Penelitian ini ditujukan untuk mendeskripsikan pelayanan administrasi serta bagaimana presepsi mahasiswa terhadap pelayanan administrasi. Ada beberapa hal yang mempengaruhi kualitas dari pelayanan administrasi, seperti sarana dan prasarana yang dimiliki serta kesadaran dari pelayan administrasi tersebut pada tugas pokoknya. Presepsi mahasiswa Prodi Pendidikan Teknik Elektro terhadap pelayanan administrasi Fakultas Teknik Elektro Universitas Negeri Padang dinyatakan kurang baik.
\end{abstract}

Kata kunci: administrasi, pelayanan administrasi, pelayanan publik

\section{Pendahuluan}

Pelayanan adminsitrasi merupakan salah satu hal yang utama dalam mengatur penyelenggaraan pendidikan pada perguruan tinggi. Pada dasarnya, pelayanan adalah kegiatan yang diberikan pada pengguna / konsumen yang sifatnya tidak terwujud. Pelayanan merupakan suatu tindakan nyata sosial. Secara kompleks pelayanan dapat disimpulkan merupakan bentuk usaha apasaja demi mencapai kepuasan pengguna jasa.

Sedangkan administrasi adalah kegiatan membantu atau melayani dalam mencapai suatu tujuan tertentu. Kegiatan administrasi ini meliputi penyusunan, pengolahan dan pencatatan data yang dilakukan secara sistematik dengan tujuan agar mempermudah menemukan data-data tersebut jika diperlukan kembali. Jadi, pelayanan administrasi dapat diartikan sebagai bantuan dalam hal melayani serta menyusun data secara sistematis. Mahasiswa merupakan salah satu yang berhubungan langsung dengan pelayanan administrasi untuk tingkat universitas. Pelayanan administrasi pada perguruan tinggi terfokus dalam hal memberikan pelayanan atau bantuan kepada mahasiswa pada kegiatan registrasi serta untuk mendapatkan bahan ajar yang mana keduanya sangat berpengaruh dalam proses belajar mahasiswa.

Terdapat beberapa permasalahan yang berkaitan dengan pelayanan administrasi di Jurusan Teknik Elekrro yang penulis dapatkan selama observasi dan beberapa keluhan dari 
mahasiswa, seperti lambannya pelayanan administrasi tersebut. Contoh kasusnya seperti pada setiap awal semester, mahasiswa akan mengisi Kartu Rencana Studi yang seharusnya terdapat jadwal dan kelas pada tiap Mata Kuliahnya, tetapi hingga waktu perkuliahan akan dimulai, waktu dan ruangan belajar masih belum tersedia di KRS online mahasiswa. Yang mengharuskan mahasiswa menunggu keluarnya jadwal tersebut di Mading Jurusan. Membuat ketidak efektifan karena banyaknya mahasiswa yang ingin mengetahui jadwal dan ruangan mereka, dan masalah ini hanya terjadi di Jurusan Teknik Elektro Universitas Negeri Padang.

\section{Metode Penelitian}

Penelitian kualitatif adalah penelitian yang bermaksud untuk memahami fenomena tentang yang dialami oleh subjek penelitian misalnya perilaku, persepsi, motivasi, tindakan, dan lain-lain. Menurut Sukmadinata (2015: 60), penelitian kualitatif (Qualitatif Research) adalah suatu penelitian yang ditujukan untuk mendeskripsikan dan menganalisis fenomena, peristiwa, aktivitas sosial, sikap, kepercayaan, persepsi, pemikiran orang secara individual maupun kelompok. Beberapa deskripsi digunakan untuk menemukan prinsip-prinsip penjelasan yang mengarah pada penyimpulan.

Jenis penelitian kualitatif adalah suatu metode dalam meneliti status kelompok manusia, suatu objek, suatu kondisi, suatu sistem pemikiran, ataupun suatu kelas peristiwa pada masa sekarang dengan tujuan untuk membuat deskripsi gambaran atau lukisan secara sistematis, faktual dan akurat mengenai fakta-fakta, sifat-sifat serta hubungan antar fenomena yang diselidiki (Sugiono, 2010: 28).

Penetapan subyek penelitian (informan penelitian) dilakukan secara purposive sampling yakni penetapan subjek penelitian berdasarkan kepada pertimbangan tertentu. Pertimbangan tertentu ini, misalnya orang tersebut yang dianggap paling tahu tentang apa yang kita harapkan, atau mungkin dia sebagai penguasa sehingga akan memudahkan peneliti menjelajahi objek/situasi sosial yang diteliti (Sugiyono, 2008: 300).Pertimbangan tertentu itu juga dapat termasuk keterlibatan subjek dengan masalah yang diteliti, pemahaman subjek terhadap persoalan yang diungkap serta kerelaan dan kesediaan subjek untuk memberikan informasi.

\section{Hasil dan Pembahasan}

Layanan berasal dari kata service, Kolter (2008: 444)

mendefinisikan service is any act and performance that one party can offer to another that is essentially intangible and does not result in the ownership of anything. Its production may or may not be tied to a phisycal product (layanan adalah setiap tindakan atau kinerja yang satu pihak dapat menawarkannya kepada pihak yang lain, yang pada dasarnya tidak berwujud dan tidak berakibat kepemilikan, apa pun produksinya mungkin tidak terikat dengan suatu produk fisik).

Secara sederhana pelayanan administrasi dapat dipahami sebagai suatu kegiatan atau usaha yang dilakukan oleh seseorang atau sekelompok orang untuk memberikan kemudahan pada pemenuhan kebutuhan pihak lain baik secara langsung maupun tidak langsung. Secara sempit, pelayanan administrasi dipahami sebagai kegiatan pelayanan di bidang ketatausahaan. Pelayanan administrasi yang dimaksud dalam penelitian ini adalah pelayanan yang berkaitan dengan pendidikan di perguruan tinggi. Berdasarkan pengertian tersebut, maka pelayanan administrasi dapat diartikan sebagai usaha yang dilakukan perguruan tinggi untuk 
memberikan kemudahan guna memenuhi kebutuhan mahasiswa dalam hal yang berkaitan dengan kegiatan administrasi.

Untuk mengukur kualitas suatu layanan, khususnya dalam hal pelayanan administrasi, dapat menggunakan lima dimensi pelayanan yang dikemukan oleh Parasuraman, Zeithml, dan Leonard L. Berry dalam "A model of Service Quality and its Implication for Future research" yang dikutip oleh Kotler (2003: 455) yang mencakup: a) reliability, b) responseveness, c) assurance, d) empathy, dan e) tangibles.

Daya tanggap atau responsiveness yaitu suatu sikap kemauan untuk membantu dan memberikan pelayanan yang cepat (responsive) dan bertindak tanggap dan tepat kepada pelanggan, dengan penyampaian yang jelas dan mudah dimengerti. Membiarkan konsumen menunggu tanpa alasan yang jelas menyebabkan persepsi yang negatif dalam kualitas pelayanan. Tuntutan pelayanan yang menyikapi berbagai keluhan dari bentuk- bentuk pelayanan yang diberikan menjadi suatu respek positif dari daya tanggap pemberi pelayanan dan yang menerima pelayanan. Seyogyanya pihak yang memberikan pelayanan apabila menemukan orang yang dilayani kurang mengerti atas berbagai syarat prosedur atau mekanisme, maka perlu diberikan suatu pengertian dan pemahaman yang jelas secara bijaksana, berwibawa dan memberikan berbagai alternatif kemudahan untuk mengikuti syarat pelayanan yang benar, sehingga kesan dari orang yang mendapat pelayanan memahami atau tanggap terhadap keinginan orang yang dilayani.

Assurance(jaminan) merupakan jaminan yang diberikan pemberi layanan yang dalam hal ini pegawai pelayanan akademik dan non akademik kepada mahasiswa. Jaminan tersebut dapat berupa kepercayaan maupun pengetahuan sehingga membuat para mahasiswa merasa tenang dan nyaman saat dilayani. Pelayanan yang berkualitas salah satunya dapat ditunjukkan oleh jaminan pelayanan yang diberikan, karena kebanyakan saat ini hal tersebut tidak dimiliki oleh para pemberi layanan sehingga dengan mudah membuat kepercayaan dari mereka yangdiberi layanan menjadi berkurang.

Adapun yang dimaksud assurance (jaminan) dalam penelitian ini adalah jaminan pelayanan yang dapat dipercaya dan jaminan atas file atau data-data mahasiswa tersimpan dengan baik dan benar.

Berdasarkan hasil wawancara peneliti dengan mahasiswa, peniliti dapat mengambil kesimpulan bahwa, masih kurangnya kesabaran dan keramahan staff/pegawai di bagian akademik/kemahasiswaan dalam melayani mahasiswa. Mahasiswa sering mengeluhkan pelayanan akademik/kemahasiswaan, mereka mengeluhkan tentang pelayanannya yang lambat, kurang begitu ramah dan terkadang mereka marah- marah dalam melayani mahasiswa.

\section{Kesimpulan dan Keterbatasan}

Pelayanan administrasi akademik di Jurusan Teknik Elektro masih kurang baik. Para pegawai sering tidak menggunakan waktu dengan efektif dan efesien sehingga pekerjaan yang sebenarnya bisa di lakukan dengan cepat akhirnya membutuhkan waktu yang lama. Kurang ramahnya pegawai administrasi pendidikan di jurusan ini membuat para mahasiswa menjadi enggan untuk bertanya dan meminta bantuan akademin pada jurusan.

Kurangnya sarana dan prasarana. Menurut staf bagian input data di Jurusan Teknik Elektro, jumlah komputer di bagian input data perlu ditambah agar dapat melakukan pelayanan yang maksimal kepada mahasiswa. 


\section{DAFTAR PUSTAKA}

Amrizal, A. (n.d.). Kualitas pelayanan administrasi akademik di fakultas keguruan dan ilmu pendidikan universitas tadulako. 73-82.

Hasbi, M. (n.d.). KEGURUAN UIN RADEN FATAH PALEMBANG Pelayanan Administrasi Fakultas. 1(2), 128-144.

Makassar, U. N. (2015). Pelayanan administrasi akademik di lingkungan program studi pendidikan administrasi perkantoran fakultas ilmu sosial universitas negeri makassar.

Pendidikan, A., \& Refleksi, S. (2009). PRAKTIK PENGALAMAN LAPANGAN PROGRAM STUDI.

Rodiyah, I., Dinas, C., \& Kecamatan, P. (n.d.). No Title. 177-190.

Yulaini, E. (2017). ADMINISTRASI SEKOLAH DALAM KEGIATAN KULIAH KERJA LAPANGAN ( KKL ) UNIVERSITAS PGRI PALEMBANG. (2), 29-42. 